\title{
INFLUENCING FACTORS OF SPORT ACTIVITIES AMONG THE EU'S POPULATION BASED ON THE EUROBAROMETER 2018
}

\section{CZYNNIKI WPEYWAJĄCE NA AKTYWNOŚĆ SPORTOWĄ WŚRÓD LUDNOŚCI UE NA PODSTAWIE EUROBAROMETRU 2018}

\author{
Dávid Paár ${ }^{1(\mathrm{~A}, \mathrm{~B}, \mathrm{D}, \mathrm{E}, \mathrm{F})}$, Pongrác Ács ${ }^{1(\mathrm{~A}, \mathrm{D}, \mathrm{G})}$, Tamás Laczkó $^{1(\mathrm{~A}, \mathrm{~B}, \mathrm{C}, \mathrm{D})}$ \\ ${ }^{1}$ Faculty of Health Sciences, University of Pécs, Hungary
}

Authors' contribution Wkład autorów: A. Study design/planning zaplanowanie badań B. Data collection/entry zebranie danych C. Data analysis/statistics dane - analiza i statystyki D. Data interpretation interpretacja danych E. Preparation of manuscript przygotowanie artykułu F. Literature analysis/search wyszukiwanie i analiza literatury G. Funds collection zebranie funduszy
Tables: 3

Figures: 1

References: 32

Submitted: 2020 Jul 2

Accepted: 2020 Aug 11

\begin{abstract}
Summary
Background. The aim of this paper is to explore the relationship between demographic, sociocultural, socioeconomic and sports infrastructural factors affecting the frequency of regular sports activity among the adult population in the European Union, with the help of an individual-level research.

Material and methods. The data analyzed are from the Special Eurobarometer 472 Sport and Physical Activity survey, conducted in 2017. All respondents $(n=28,031)$ were over 15 years of age and resident in one of the $28 \mathrm{EU}$ member states. Descriptive statistical methods, chi-square tests and binary logistic regression model were used in the analysis.

Results. Regular sports activity was significantly influenced by demographic factors (age and gender), quality of life factors (health status and life satisfaction) and sports infrastructural factors from the 12 factors included in the regression model. The sports habits of adults living in the EU are also significantly influenced by sociocultural, as well as socioeconomic factors.

Conclusions. This paper highlights that social, cultural and economic structures, as well as the infrastructural factors of sport played a key role in shaping the sports habits of the EU adult population in 2017.
\end{abstract}

Keywords: sports, leisure activities, European Union, sociological factors, socioeconomic factors

\section{Streszczenie}

Wprowadzenie. Celem niniejszej pracy jest zbadanie zależności między czynnikami demograficznymi, społeczno-kulturowymi, społeczno-ekonomicznymi oraz wynikającymi z infrastruktury sportowej, które wpływają na częstotliwość regularnej aktywności sportowej wśród dorosłej populacji Unii Europejskiej za pomocą badań na poziomie indywidualnym.

Materiał i metody. Analizowane dane pochodzą z badania Eurobarometr 472 Sporti aktywność fizyczna, przeprowadzonego w $2017 \mathrm{r}$. Wszyscy respondenci (n=28031) to osoby powyżej 15. roku życia z 28 krajów UE. W analizie wykorzystano opisowe metody statystyczne, testy chikwadrat oraz binarny model regresji logistycznej.

Wyniki. Spośród 12 czynników uwzględnionych w modelu regresji istotny wpływ na regularną aktywność sportową miały zwłaszcza czynniki demograficzne (wiek i płeć), czynniki związane z jakością życia (stan zdrowia i zadowolenie z życia) oraz czynniki powiązane z infrastrukturą sportową. Znaczący wpływ na nawyki sportowe osób dorosłych mieszkających w UE miały również czynniki społeczno-kulturowe i społeczno-ekonomiczne.

Wnioski. Niniejsza praca podkreśla fakt, że struktury społeczne, kulturowe i gospodarcze, a także czynniki związane $\mathrm{z}$ infrastrukturą sportową odegrały kluczową rolę $\mathrm{w}$ kształtowaniu nawyków sportowych wśród dorosłej populacji UE w 2017 roku.

Słowa kluczowe: sport, zajęcia rekreacyjne, Unia Europejska, czynniki socjologiczne, czynniki socjoekonomiczne 


\section{Introduction}

The literature on the study of factors influencing physical activity and sports habits among the population is relatively extensive. Various studies focus on the analysis of demographic, sociocultural, socioeconomic, quality of life, psychological, and sports infrastructural factors typically [1-7]. Our research also falls in line with the aim of analyzing whether there is a shift based on the latest European trends compared to previous results.

Sports consumers need to make decisions about the use of their disposable time and income; on one hand, they are producers of their own sports activity, on the other they are a consumer of it, based on the time allocation theory [1]. The heterodox sports consumption models expand the range of explanatory variables with microand macro-level sociological, demographic, psychological and other temporal and spatial aspects [2-4]. Others included explanatory variables from the supply side of sports market into their analyses [5-7].

Examining gender differences, the vast majority of studies suggested that men are more likely to play sports and spend more time with this activity than women [2,8,9]; Breuer and Wicker showed that these differences decrease with age [10], with the willingness to participate in sports showing a declining trend among the older population $[2,8,9]$. Regarding health status, those suffering from chronic illnesses are less likely to play sports compared to healthy individuals [8,9]. Providing better and more sports opportunities also results in higher willingness to do sports [5,6], whilst level of education shows a positive correlation with this also [2,10]. As household size increases, the willingness to participate in sports decreases, in most cases [11]. The willingness of married people to do sports is lower than singles - although conflicting results have been found, also [12]. The lack of an adequate income can be seen as a barrier to participation in recreational sports [9], as higher income increases the likelihood of participation in sports [13,14]; indeed, several studies have confirmed the luxury characteristics of sports $[15,16]$. Also of note, employee status has been negatively correlated with the probability of recreational sports participation in most researches $[9,13]$.

A review of comprehensive analyses made from Eurobarometer databases is important to assess the present study. Hovemann and Wicker have examined the participation in sport by logistic regressions for the EU and for the member states separately based on the 2004 Eurobarometer database $[17,18]$. Van Tuyckom and Scheerder also used the physical activity binary variable $(0=$ completely physically inactive person) as a dependent variable in their Hierarchical Linear Modelling based on the 2005 Eurobarometer database [19,20]. Downward et al. used the ZIOP model for the 2009 Eurobarometer [21,22]; their dependent variable was a binary one measuring the willingness to do sports $(0=$ person who never does any sports). Lera-López and Marco have researched physical activity at the level of EU regions based on the 2014 Eurobarometer survey database [23,24].

The aim of our analysis was to explore the relationship between demographic, sociocultural, socioeconomic and sports infrastructural factors affecting the frequency of regular sports activities, with the help of an individual-level study among the population of the European Union.

\section{Material and methods}

We analyzed the data collected by the European Commission in December 2017, spanning all 28 member states [25]. A research sample group of 28,031 individuals (15 years of age or older) was selected using multistage stratified systematic sampling (sampling points were drawn from administrative regional units, starting addresses were selected randomly, and all further addresses were selected by random route process). The sample is representative of the European Union's countries and regions regarding gender, age, and type of settlement (rural area or village, small/middle town, large town).

Participating in regular sports activities was included in our analysis as a dependent, binary variable, while 12 demographic, sociocultural, socioeconomic, quality of life, and sports infrastructural factors were included as independent variables. Those who performed sporting activity at least three times per week were categorized as regularly active; this category was obtained by combining the Eurobarometer categories 'sports activities at least 5 times a week' and 'sports activities 3-4 times a week'. This frequency is closest to the minimum amount of exercise optimally expected for complex physical health improvement, which is articulated by professionals as a total of 150 minutes of sports activities 3 times a week [26]. The definition of this category was also justified by the fact that exercising at least three times a week has a positive effect on mental health [27] and quality of life [28]; in addition, members of this category show significantly greater openness for passive sports consumption, which can also be clearly identified in the sports spending, also [3]. Information on the frequency of participating in sports were self-reported.

The sports habits of the EU population were analyzed using distribution rates and differences at state level, whilst the effects of influencing factors were examined by chi-square tests and a binary logistic regression 
model $(\mathrm{p}<0.05)$. Since the chi-square test is only valid for testing the relationship between two variables, we used the Enter type of binary logistic regression model to quantify the interacting effects of several variables. There was no multicollinearity between the variables included in the regression model based on the variance inflation factor (VIF) values.

\section{Results}

Examining the sports habits typical for the countries of the European Union it can be stated that $8 \%$ of the population participated in sports on a daily basis in 2017, another $11 \%$ did so 3-4 times a week, with a further $18 \%$ engaging 1-2 times a week. In contrast to regular sports activities, almost half of the population (47\%) answered that they never do sports, while a further $16 \%$ had very low levels of sports activity (1-3 times a month or less).

Examining the proportion of people being active in sports at least three times a week in member states, it can be stated that the highest values are for the Scandinavian, Ireland, UK, BeNeLux, Slovenia and Spain, while the lowest frequencies are seen in Central and Eastern Europe (Bulgaria, Romania, Poland, Croatia, Slovakia) and Southern Europe (Greece, Italy, Portugal) (Figure 1). Comparing the values of Finland and Bulgaria, which are the most and least active nations (according to this survey), we see a difference of greater than 5.5 times. Extending the examination of the ratios to the average values of the 5 most and least sporty countries, the difference is still 3.8 times; this has been proven to be statistically significant $\left(\chi^{2}=1605.41 ; p<0.001\right)$. It can be stated that the proportion of people with sports activities at least three times a week is significantly higher than the EU average in Finland, Sweden, Ireland, Denmark, Great Britain, Luxembourg, Slovenia, Spain and the Netherlands. However significantly lower values are found in Hungary, France, Austria, Latvia, Estonia, Czech Republic, Poland, Croatia, Slovakia, Greece, Portugal, Italy, Romania and Bulgaria (Figure 1).

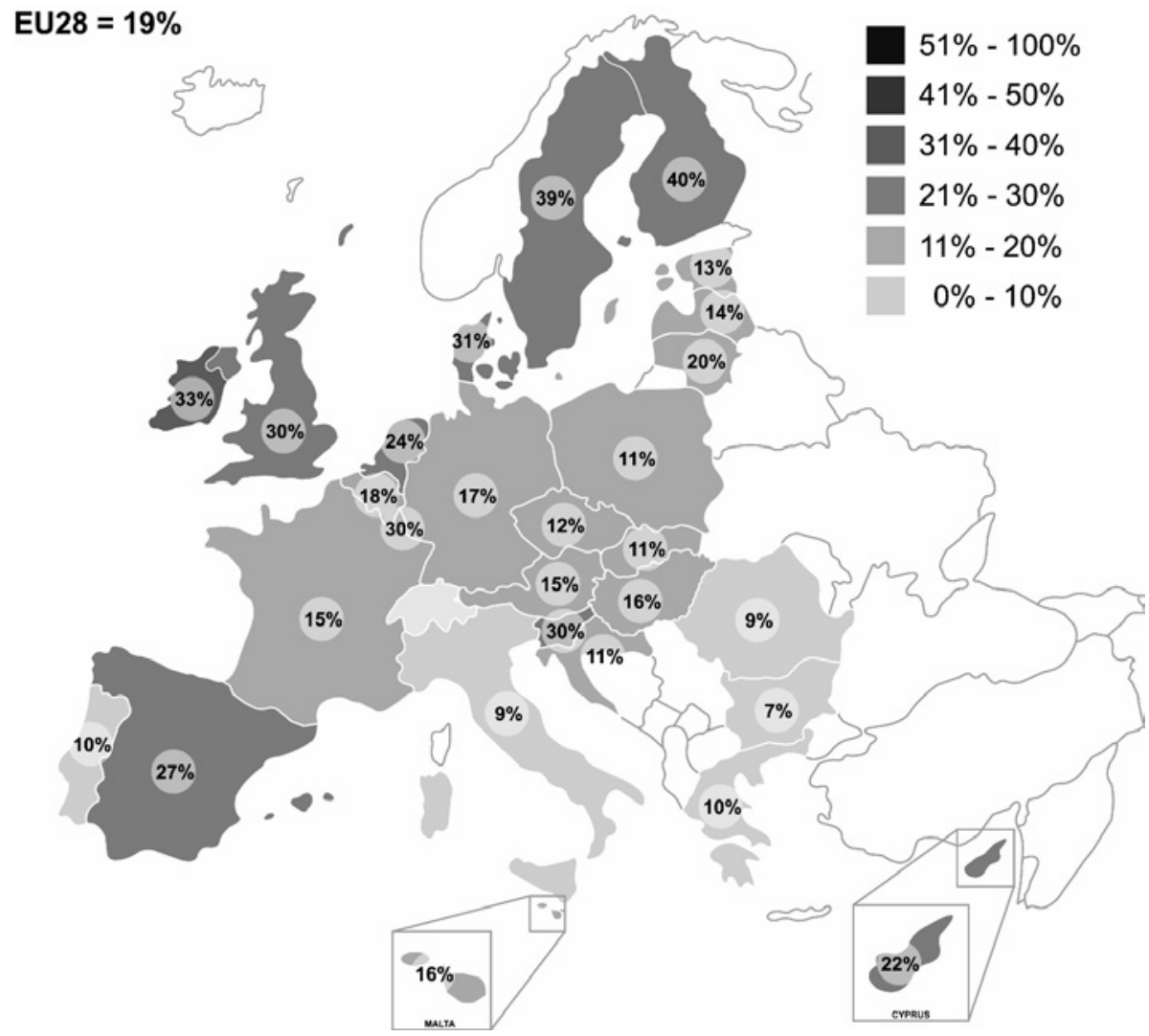

Figure 1. Proportion of people over 15 years of age being regularly active in sports in the EU (\%) [25]

It was observed that 11 factors had an effect on the presence of regular sports activities, after controlling all the explanatory variables involved in the binary logistic model. The demographic, quality of life, sports infrastructure, sociocultural and socioeconomic factors shown in Table 1 explain 10.6\% (Nagelkerke $\mathrm{R}^{2}$ ) of the possibility of performing sports at least three times a week among the population of EU countries. 
Table 1. Relationship between the factors included in the research and the presence of regular sports activities (Chi-square test and binary logistic regression, $n=28,031$ )

\begin{tabular}{|c|c|c|c|c|}
\hline \multirow[t]{2}{*}{ Variable } & \multicolumn{3}{|c|}{ Chi-square test } & \multirow{2}{*}{$\begin{array}{c}\begin{array}{c}\text { Binary logistic } \\
\text { analysis }\end{array} \\
\text { p value } \\
\end{array}$} \\
\hline & test statistics & p value & Cramer's V & \\
\hline \multicolumn{5}{|l|}{ Demographic factors: } \\
\hline gender & 102.6 & $<0.001$ & 0.060 & $<0.001$ \\
\hline age & 384.2 & $<0.001$ & 0.117 & $<0.001$ \\
\hline \multicolumn{5}{|l|}{ Quality of life factors: } \\
\hline health status (self-reported) & 670.9 & $<0.001$ & 0.155 & $<0.001$ \\
\hline life satisfaction (self-reported) & 834.7 & $<0.001$ & 0.173 & $<0.001$ \\
\hline \multicolumn{5}{|l|}{ Sports infrastructural factor: } \\
\hline $\begin{array}{c}\text { sports opportunities of the settlement (based on } \\
\text { subjective evaluation) }\end{array}$ & 396.3 & $<0.001$ & 0.119 & $<0.001$ \\
\hline \multicolumn{5}{|l|}{ Sociocultural factors: } \\
\hline educational level & 326.1 & $<0.001$ & 0.108 & $<0.001$ \\
\hline type of community & 9.4 & 0.009 & 0.018 & 0.682 \\
\hline marital status & 249.2 & $<0.001$ & 0.094 & $<0.001$ \\
\hline \multicolumn{5}{|l|}{ Socioeconomic factors: } \\
\hline income situation of the household & 233.7 & $<0.001$ & 0.101 & 0.047 \\
\hline social status & 528.8 & $<0.001$ & 0.139 & $<0.001$ \\
\hline occupational status & 540.5 & $<0.001$ & 0.139 & $<0.001$ \\
\hline living environment status & 359.1 & $<0.001$ & 0.114 & $<0.001$ \\
\hline Nagelkerke $\mathbf{R}^{2}$ & \multicolumn{4}{|c|}{0.106} \\
\hline Model $\chi^{2}(\mathrm{df}=41)$ & \multicolumn{4}{|c|}{$1485.441(p=<0.001)$} \\
\hline
\end{tabular}

Regarding demographic factors, it is clear (Table 2) that male dominance is still visible in the case of regular sports, as we can find men $27.4 \%$ more likely doing sports three times a week compared to women. It can also be said that the proportion of people performing regular sports activities is higher in younger age groups; compared to respondents over 75 years of age, the proportion of people doing sports at least three times a week is much higher (59.6\%) among the youngest (15-24 years old) category, and the 25-34 years of age category (25.8\%). Indeed, the proportion of people regularly participating in sports is higher in all age groups compared to those aged 75 years and over, however the next age group with lowest participation rate is 35-44 years. The proportion of people with regular sporting activity tends to increase slightly from middle-age (35-44 years) up to $64-75$ years.

Table 2. Relationship between regular sports activities and demographic, quality of life and sports infrastructure factors $(\mathrm{n}=28,031)$

\begin{tabular}{|c|c|c|c|c|}
\hline \multirow{2}{*}{ Variable } & \multirow{2}{*}{$\begin{array}{l}\text { Categories of } \\
\text { the variable }\end{array}$} & \multirow{2}{*}{$\operatorname{Exp}(B)$} & \multicolumn{2}{|c|}{ 95\% CI for $\operatorname{Exp(B)}$} \\
\hline & & & Lower & Upper \\
\hline \multicolumn{5}{|l|}{ Gender } \\
\hline Reference: women & men & 1.274 & 1.185 & 1.369 \\
\hline \multicolumn{5}{|l|}{ Age } \\
\hline \multirow{6}{*}{ Reference: 75 years and older } & $15-24$ years & 1.596 & 1.249 & 2.039 \\
\hline & 25-34 years & 1.258 & 1.031 & 1.535 \\
\hline & 35-44 years & 1.049 & 0.863 & 1.275 \\
\hline & $45-54$ years & 1.073 & 0,886 & 1.298 \\
\hline & 55-64 years & 1.099 & 0.931 & 1.297 \\
\hline & $65-74$ years & 1.130 & 0.982 & 1.299 \\
\hline \multicolumn{5}{|l|}{ Health status } \\
\hline \multirow{4}{*}{ Reference: strongly disagree } & strongly agree & 2.038 & 1.551 & 2.679 \\
\hline & agree & 1.540 & 1.177 & 2.015 \\
\hline & $\begin{array}{l}\text { neither agree } \\
\text { nor disagree }\end{array}$ & 1.113 & 0.839 & 1.477 \\
\hline & disagree & 1.160 & 0.872 & 1.544 \\
\hline
\end{tabular}




\begin{tabular}{|c|c|c|c|c|}
\hline Life satisfaction & \multicolumn{5}{|l|}{1.914} & 3.875 \\
\hline \multirow{4}{*}{ Reference: not satisfied } & very satisfied & 2.723 & 1.480 & 2.957 \\
\cline { 2 - 5 } & fairly satisfied & 2.092 & 0.887 & 1.816 \\
\cline { 2 - 5 } & $\begin{array}{c}\text { not very satis- } \\
\text { fied }\end{array}$ & 1.270 & 1.405 & 1.684 \\
\hline Sports opportunities of the settlement (many sport opportunities in area) & 1.538 & agree & &
\end{tabular}

Among the indicators of quality of life, health status and life satisfaction also had a significant effect on the willingness to participate in regular sports activities (Table 2). Taking into consideration the subjective assessment of health status, the proportion of people performing regular sports activities is lowest in respondents who rated their health as the most unfavorable. Compared to this group, we see that members of most favorable group are twice as likely to be regularly active, and members of second favorable group have a $54 \%$ higher possibility of being regularly active.

We can see that the proportion of regularly active people is lowest among the people who are most dissatisfied with their lives, when we assess the complex subjective quality of life. Compared to this group, regular sports activities are 2.7 times and twice as likely in the groups of respondents who are completely and fairly satisfied with their lives, respectively.

The availability of sports opportunities in the living environment also significantly influenced the regular sports frequency of individuals. The proportion of regularly active people is more than $50 \%$ higher among those who agreed that the region in which they live offers many sports opportunities, compared to those who rate their opportunities more poorly.

Education and family situation had a significant influencing effect on sports activities from sociocultural factors after regressing the variables (Table 3). The presence of regularly active people is higher among the more educated. This is illustrated by the fact that respondents with at least a master's or doctoral degree have a $25.5 \%$ higher rate, while respondents with a bachelor's degree have a $12.1 \%$ higher presence in the regularly active group, compared to those who have not completed primary education. We find the lowest odds ratio among people with a secondary education, but the difference between the group with the lower educational level is not significant.

Considering marital status, those who are unmarried and divorced participate in sports most often; we observed more than $26 \%$ less ratio among people living in a relationship or marriage or widowed.

Table 3. Relationship between regular sports activities and sociocultural and socioeconomic factors (n=28,031)

\begin{tabular}{|c|c|c|c|c|}
\hline \multirow{2}{*}{ Variable } & \multirow{2}{*}{ Categories of the Variable } & \multirow{2}{*}{$\operatorname{Exp}(B)$} & \multicolumn{2}{|c|}{ 95\% CI for $\operatorname{Exp(B)}$} \\
\hline & & & Lower & Upper \\
\hline \multicolumn{5}{|l|}{ Educational level } \\
\hline \multirow{4}{*}{ Reference: not completed } & completed primary & 0.906 & 0.661 & 1.242 \\
\hline & completed secondary & 0.894 & 0.656 & 1.217 \\
\hline & $\begin{array}{c}\text { completed bachelor level } \\
\text { or equivalent }\end{array}$ & 1.121 & 0.821 & 1.531 \\
\hline & $\begin{array}{c}\text { completed master or doctoral } \\
\text { degree }\end{array}$ & 1.255 & 0.910 & 1.731 \\
\hline \multicolumn{5}{|l|}{ Marital status } \\
\hline \multirow{4}{*}{$\begin{array}{l}\text { Reference: unmarried } \\
\text { (without partner) }\end{array}$} & married/single with partner & 0.784 & 0.707 & 0.869 \\
\hline & divorced or separated & 1.060 & 0.909 & 1.236 \\
\hline & widowed & 0.792 & 0.671 & 0.934 \\
\hline & other & 0.840 & 0.534 & 1.323 \\
\hline \multicolumn{5}{|c|}{ Income situation of the household } \\
\hline \multirow{4}{*}{ Reference: lower quintile } & 2nd quintile & 1.059 & 0.954 & 1.176 \\
\hline & 3rd quintile & 1.052 & 0.939 & 1.180 \\
\hline & 4th quintile & 1.083 & 0.954 & 1.229 \\
\hline & upper quintile & 1.233 & 1.074 & 1.416 \\
\hline
\end{tabular}




\begin{tabular}{|c|c|c|c|c|}
\hline \multicolumn{5}{|l|}{ Social status } \\
\hline \multirow{2}{*}{ Reference: bottom } & middle & 1.357 & 1.156 & 1.593 \\
\hline & top & 1.681 & 1.416 & 1.995 \\
\hline \multicolumn{5}{|l|}{ Occupational status } \\
\hline \multirow{7}{*}{ Reference: self-employed } & managers & 0.956 & 0.816 & 1.119 \\
\hline & other white collars & 0.793 & 0.674 & 0.933 \\
\hline & manual workers & 0.854 & 0.734 & 0.994 \\
\hline & house persons & 0.894 & 0.708 & 1.130 \\
\hline & unemployed & 1.246 & 1.020 & 1.523 \\
\hline & retired & 1.311 & 1.102 & 1.560 \\
\hline & students & 1.516 & 1.199 & 1.917 \\
\hline \multicolumn{5}{|l|}{ Living environment status } \\
\hline \multirow{4}{*}{ Reference: very poor } & fairly poor & 0.827 & 0.569 & 1.203 \\
\hline & average & 1.021 & 0.715 & 1.458 \\
\hline & fairly rich & 1.214 & 0.842 & 1.750 \\
\hline & very rich & 1.371 & 0.873 & 2.154 \\
\hline
\end{tabular}

All the four socioeconomic factors included in the research (Table 3) have an independent effect on regular sports habits. We observed that those belonging to the lowest income quintile have the lowest proportion of regularly active respondents, while those living in the most favorable situation are the most regularly sporty. There is no significant difference between the second, third and fourth quintiles in the proportion of regularly active people.

Even social status has a significant impact on the willingness to participate in sports; it is clear from the data that a more favorable status is linked to more favorable sports habits. Regularly active people were $35.7 \%$ more likely in the middle ranked social group and $68.1 \%$ more likely in the top social group, compared to those who ranked themselves in the most disadvantaged social group.

Respondents' occupational status also significantly influenced their sports habits, based on the regression model. The least regularly sporty groups are other white collar and manual workers, as well as house persons. The groups with the most favorable regular sports habits were students and, somewhat surprisingly, retired and the unemployed people among the population of EU countries. The groups of self-employed as a reference category and managers have a significantly worse situation compared to students, but they are significantly more favorable than other white collar and manual workers.

Living environment status influences the willingness to participate in sports significantly, but relatively small differences are present between the categories. Regular sports activities were least characteristic of those living in fairly poor living environments, with the proportions of regularly active people increasing with the improvement of the living environment. We found a $37.1 \%$ higher rate among respondents living in the richest living environment compared to the poorest ones.

\section{Discussion}

Approximately $19 \%$ of the EU population over the age of 15 participates in sport at least three times per week; there are still significant differences between EU member states and groups of countries, confirming the results of Lera-López and Marco [23] and Van Tuyckom and Scheerder [19].

Regular sports activity is significantly higher for men and younger age groups, based on the examination of demographic factors. The frequency of sports for women is increasing and approaching that for men but in the case of regular sports activity it still shows a male surplus [10,19]. Our results did not support the findings of Hovemann and Wicker, that women were more likely to do sports than men [17]. There is no significant reduction in the possibility of regular sports activity in terms of age compared to middle-aged groups, with the exception of those over 75 years of age. Possible reasons for this may include the fact that exercising is stably integrated into a regular sporty lifestyle, and this prevents the significant decrease over time due to the better quality of life that it provides. More leisure time for older people can also help to maintain sports activities [21]. 
A positive correlation between regular sports activities and better health status, and life satisfaction, as subjective indicators of quality of life has already been found $[28,29]$. However, it must be stated that quality of life is a complex phenomenon and its measurement is limited only by these two variables.

Sociocultural factors (educational level and marital status) also have an impact on sports activities among the EU population. Higher educational level meant a significantly higher willingness to do regular sporting activity, while those with secondary education did not differ significantly from the group with lower education levels. Living in a family is associated with a significantly lower frequency of regular sports activities than a single or divorced situation; all of these are consistent with previous findings in the literature [17,21]. However, significant differences in the presence of regular sports activities exist when considering the type of community in which the respondent resides, although this factor alone does not have a statistically significant effect in the regression model, which disagrees with the results of Van Tuyckom and Scheerder [19].

There is also a clear positive relationship between regular sports activities and income situation, social status, and living environment; the more favorable situation for all three factors increases the possibility of regular sports activities [13,14]. Students, managers, self-employed, and retired people have the highest proportions of regular sports activities, but also a relatively high proportion exists among the unemployed. Students had the highest likelihood of regular sports activities - which is fundamentally not a new finding [2]. They are followed by retired respondents, which is in agreement with Kokolakakis et al. regarding the English public [2]. We can assume that this may be the case in EU countries with higher living standards, which can also affect the entire sample. The third ranked category is the unemployed, which in turn is certainly surprising, based on the results of Widdop et al. [8]. The self-employed and managers have significantly lower odds ratios compared to these previous groups. The lowest regular sports activities' odds ratios were in the group of other white collars, manual workers, and house persons.

The role of sports infrastructure, and the wider range of sports supply, had also been clearly demonstrated in influencing regular sports activities among the EU population, as it has been confirmed by several other previous analyses [5,6]. These individual-level results confirm our previous macro-level study, in which the strongest explanatory factor of the differences in sports activities between the EU countries was the development of sports infrastructure and supply in years 2009, 2013 and 2017 [30]. National governments should play a highlighted role in developing sports infrastructure and furthermore in creating a supporting tax environment facilitating the accessibility for sports possibilities [31].

\section{Limitations}

A limited set of variables was available as a result of the Eurobarometer questionnaire in the research process. The explanatory power of the model could be increased with the expansion of independent variables in the future, e.g., sports socialization factors. Examining the relationship between sports frequency and sports motivations may further deepen the segmentation of sports consumer groups in the future, however it was not possible in the present study.

\section{Conclusions}

Our analysis, based on the 2017 Eurobarometer database [25] representing the whole population of the EU, aimed to examine how different factors can influence regular sports activities at the individual micro-level. Our research differs from similar researches based on previous Eurobarometer databases, in that they were more permissive in terms of the dependent variable and also included lower frequency of sports activities [17,19,21].

It can be said that 11 factors remained significant, even after controlling the interacting effects of the total of 12 demographic, quality of life, sports infrastructural, sociocultural and socioeconomic variables built into our model. The role of these factors in shaping sports habits is known separately, and in relation to smaller populations in different studies, however we think it was important to show in our analysis how they affect the population of the European Union, which exceeded 500 million people in 2017.

Regarding the factors influencing the frequency of regular sports activities, it can be stated that these factors can be changed only over a long period of time, and great efforts are needed to do this, as their pattern can be considered quite stable and country-specific all over the European Union [17]. In addition to this, the results highlight the role of sports infrastructure; developing this may be one of the most effective tools for positively influencing sports habits in EU countries. However, the investments into facilities must follow the ever changing consumer needs, and it must be amended by continuous and general education about healthy lifestyle, also [7,32]. 


\section{Disclosures and acknowledgements}

The publication costs were partially funded by the Human Resource Development Operational Program, grant No.: HRDOP-3.6.2-16-2017-00003, Cooperative Research Network in Economy of Sport, Recreation and Health. The authors declare that the study design; collection, management, analysis, and interpretation of data; writing of the manuscript are independent of Human Resource Development Operational Program. The authors declare that they have no competing interests.

\section{References:}

1. Becker GS. A theory of the allocation of time. The Economic Journal. 1965; 75: 493-517. https://doi.org/10.2307/2228949

2. Kokolakakis T, Lera-Lopez F, Panagouleas T. Analysis of the determinants of sports participation in Spain and England. App Econ. 2011; 44(21): 2785-2798. https://doi.org/10.1080/00036846.2011.566204

3. Kovács A, Paár D, Elbert G, Welker Z, Stocker M, Ács P. [Survey of sports consumption habits of Hungarian households]. Pécs: Faculty of Health Sciences, University of Pécs; 2015 (in Hungarian).

4. Schütoff U, Pawlowski T. Seasonal variation in sports participation. J Sports Sci. 2017; 36(4): 469-475. https://doi.org/10.1080/02640414.2017.1316864

5. Hallmann K, Wicker P, Breuer C, Schönherr L. Understanding the importance of sport infrastructure for participation in different sports - findings from multi-level modeling. European Sport Management Quarterly. 2012; 12: 525-544. https://doi.org/10.1080/16184742.2012.687756

6. Wicker P, Hallmann K, Breuer C. Micro and macro level determinants of sport participation. Sport, Business and Management: An International Journal. 2012; 2: 51-68. https://doi.org/10.1108/20426781211207665

7. Dallmeyer S, Wicker P, Breuer C. The relationship between sport-related government spending and sport and exercise participation: the role of funding size, period, and consistency. Int J Health Prom Educ. 2018; 56(45): 237-247. https://doi.org/10.1080/14635240.2018.1452623

8. Widdop P, King N, Parnell D, Cutts D, Millward P. Austerity, policy and sport participation in England. Int J Sport Policy Politics. 2018; 10(1): 7-24. https://doi.org/10.1080/19406940.2017.1348964

9. Eakins J. An analysis of the determinants of sports participation and time spent in different sporting contexts. Managing Sport and Leisure. 2018; 23(3): 157-173. https://doi.org/10.1080/23750472.2018.1527713

10. Breuer C, Wicker P. Demographic and economic factors concerning the inclusion in the German sport system. A micro-analysis of the years 1985 to 2005. Europ J Sport Soc. 2008; 5(1): 33-42. https://doi.org/10.1080/16138171.2008.11687807

11. Downward P. Exploring the economic choice to participate in sport: results from the 2002 General Household Survey. Int Rev Appl Econ. 2007; 21(5): 633-653. https://doi.org/10.1080/02692170701474710

12. Lee YG, Bhargava V. Leisure time: do married and single individuals spend it differently?. Family \& Consumer Sciences. 2004; 32(3): 254-274. https://doi.org/10.1177/1077727X03261631

13. Lera-López F, Rapún-Gárate M. Determinants of sports participation and attendance: differences and similarities. Int J Sports Marketing Sponsorship. 2011; 12(2): 66-89. https://doi.org/10.1108/IJSMS-12-022011-B007

14. Humphreys B, Ruseski J. An economic analysis of participation and time spent in physical activity. The B.E. Journal of Economic Analysis \& Policy. 2011; 11(1): 1-38. https://doi.org/10.2202/1935-1682.2522

15. Paár D. The income and price dependency of the Hungarian sport goods consumption. Periodica Polytechnica Social and Management Sciences. 2011; 19(1): 11-17. https://doi.org/10.3311/pp.so.2011-1.02

16. Pawlowski T, Breuer C. Expenditure elasticities of the demand for leisure services. Appl Econ. 2012; 44(26): 3461-3477. https://doi.org/10.1080/00036846.2011.577021

17. Hovemann G, Wicker P. Determinants of sport participation in the European Union. Europ J Sport Soc. 2009; 6(1): 51-59. https://doi.org/10.1080/16138171.2009.11687827

18. European Commission. Eurobarometer - The citizens of the European Union and sport [Internet]. Brussels: European Commission; 2004 [cited 2020 Jun 16]. Available from: https://ec.europa.eu/commfrontoffice/ publicopinion/archives/ebs/ebs_213_report_en.pdf

19. Van Tuyckom C, Scheerder J. A multilevel analysis of social stratification patterns of leisure-time physical activity among Europeans. Sci Sports. 2010; 26(6): 304-311. https://doi.org/10.1016/j.scispo.2010.04.003

20. European Commission. Eurobarometer - Health and food [Internet]. European Commission: Brussels; 2006 [cited 2020 Jun 16]. Available form: https://ec.europa.eu/commfrontoffice/publicopinion/archives/ebs/ ebs_246_en.pdf 
21. Downward P, Lera-López F, Rasciute S. The correlates of sports participation in Europe. Europ J Sport Sci. 2014; 14(6): 592-602. https://doi.org/10.1080/17461391.2014.880191

22. European Commission. Eurobarometer - Sport and physical activity [Internet]. European Commission: Brussels; 2010 [cited 2020 Jun 16]. Available from: http://ec.europa.eu/commfrontoffice/publicopinion/ archives/ebs/ebs_334_en.pdf

23. Lera-López F, Marco R. Sports participation, physical activity, and health in the European regions. J Sports Sci. 2018; 36(15): 1784-1791. https://doi.org/10.1080/02640414.2017.1418810

24. European Commission. Eurobarometer - Sport and physical activity [Internet]. European Commission: Brussels; 2014 [cited 2020 Jun 16]. Available from: http://ec.europa.eu/commfrontoffice/publicopinion/ archives/ebs/ebs_412_en.pdf

25. European Commission. Eurobarometer - Sport and physical activity [Internet]. European Commission: Brussels; 2018 [cited 2020 Jun 16]. Available from: http://ec.europa.eu/commfrontoffice/publicopinion/ index.cfm/survey/getsurveydetail/instruments/special/surveyky/2164

26. American College of Sports Medicine. ACSM's guidelines for exercise testing and prescription. 9th Edition. Philadelphia: Lippincott Williams \& Wilkins; 2013.

27. Harvey SB, Overland S, Hatch SL, Wessely S, Mykletun A, Hotopf M. Exercise and the prevention of depression: results of the HUNT cohort study. Am J Psych. 2017; 175: 28-36. https://doi.org/10.1176/appi.ajp.2017.16111223

28. Gémes K. [Sport and quality of life]. In: Kopp M, Kovács ME., editors. [Hungarian population's quality of life at the turn of the millennium]. Budapest: Semmelweis Publishing; 2006. p. 167-180 (in Hungarian).

29. Stocker MG. Value creation of knowledge-intensive companies. Budapest: Corvinus University of Budapest; 2012.

30. Laczkó T, Sánta V, Paár D. [The effects of macro factors influencing sports habits in the countries of the European Union]. Magyar Sporttudományi Szemle. Forthcoming 2020 (in Hungarian).

31. Gősi Z. [Some economic effects of leisure time sport]. In: Gősi Z, Boros S, Patakiné Bősze J., editors. [Diverse recreation: studies on the subject of recreation]. Budapest: Faculty of Pedagogy and Psychology, Eötvös Loránd University; 2019. p. 69-85 (in Hungarian).

32. Jaworek M, Karaszewski W, Kuczmarska M, Kuzel M. Investment expenditure on sport infrastructure in Poland: diagnosis, general trends, and possible prospects. J Phys Ed Sport. 2020; 154, 1106-1114. https://doi.org/10.7752/jpes.2020.s2154 